\title{
REMOVAL OF DISSOLVED METHANE AND OTHER CONTAMINANTS FROM LANDFILL LEACHATES IN ENGINEERED WETLANDS
}

\section{Tim Robinson *}

Phoenix Engineering, Phoenix House, Scarne Mill Industrial Estate, Launceston, Cornwall, PL15 9GL, United Kingdom

Article Info:
Received:
1 November 2019
Revised:
23 December 2020
Accepted:
10 January 2020
Available online:
11 February 2020
Keywords:
Methane removal
Wetlands
Reed beds
Landfill leachate
Leachate treatment
Wastewater treatment

\section{INTRODUCTION}

An alternative option to installing bespoke methane stripping systems at older landfills, where COD values and concentrations of ammoniacal- $\mathrm{N}$ may be starting to reduce, is to pass raw leachates through engineered wetlands in the form of reed beds. Dissolved methane is readily-degraded and oxidised by bacteria, preferentially before other COD components, because of the high energy available to the bacteria. Therefore, complete removal of the dissolved methane can potentially be achieved in a passive, and low maintenance system. This is important at closed and unmanned landfill sites.

The disposal of landfill leachates into public sewers, for combined treatment with domestic wastewaters, remains a common practice at many landfill sites. Leachates can typically contain concentrations of dissolved methane of up to $15 \mathrm{mg} / \mathrm{l}$, and from first principles it can be determined that at concentrations of $1.4 \mathrm{mg} / \mathrm{l}$ or greater, explosive concentrations of methane gas can be generated in the headspace above such leachate, and potentially within the sewer itself (Robinson et.al, 1999). As a result, regulators in the United Kingdom routinely apply a factor of safety of ten, resulting in discharge limits of less than $0.14 \mathrm{mg} / \mathrm{l}$ for concentrations of dissolved methane in leachates being discharged.

This can therefore result in a need to reduce original concentrations of dissolved methane by more than 99 per cent, from $15.0 \mathrm{mg} / \mathrm{l}$ to less than $0.14 \mathrm{mg} / \mathrm{l}$, on a reliable basis, requiring sound process designs and robust treatment systems. Even though rates of gas production may be much lower at relatively old and closed landfill sites, concentrations of methane gas can remain at $60 \%$ within the landfill mass, and so concentrations of dissolved methane in leachates often remain high for many decades.

Dissolved methane is readily degraded biologically in suitable aerobic conditions, and many relatively simple filter systems have been used successfully for this purpose (Hatamoto et.al, 2010). In landfill environments, the oxidation of methane in landfill gas, has regularly been 
observed to take place in the presence of naturally occurring methanotrophs (Stern et.al, 2007). Methane is readily oxidised biologically by these bacteria, in the presence of oxygen. Therefore, because oxygen enters the reed beds by passive diffusion, assisted to some extent by oxygen transfer via the reed plants, methane can be removed successfully. This removal has been demonstrated at Shirley reedbed, where methane levels must satisfy a $0.14 \mathrm{mg} / \mathrm{l}$ discharge consent (Robinson, H., 2017; Robinson, T., 2017; 2018).

Methane stripping systems can, and have been installed to remove dissolved methane, prior to the safe discharge of pre-treated leachates into the public sewer, for combined treatment with domestic wastewaters, but the stripping process requires power, frequent maintenance, and can result in precipitation of large amounts of scale as calcium, magnesium and iron are brought out of solution by the vigorous aeration involved (Robinson, 1999; Robinson et.al, 1999).

Reed bed systems have been used successfully both for the complete treatment of relatively weak leachates from old, closed landfills (Robinson, 1999; Robinson et.al, 1999), and also for the polishing of leachates that have been treated biologically, in order to enable effluents to be discharged safely into surface watercourses (Robinson, 1993, 1999; Robinson et.al, 2003; 2008; Robinson and Olufsen, 2007; Strachan et.al, 2007; Novella et.al, 2004). In almost all circumstances, greatest success has been achieved where concentrations of ammoniacal- $\mathrm{N}$ in liquids entering the reed bed do not exceed $10 \mathrm{mg} / \mathrm{l}$, whether beds are operated as vertical or horizontal flow systems.

Reed beds have great potential to provide an environment in which effective biological oxidation and degradation of methane dissolved in leachates from closed landfill sites can reliably and efficiently achieve concentrations acceptable for discharge into public sewers, but few case studies have been reported.
This paper reports and describes in detail a full-scale project at a closed landfill in the UK Midlands, where a reed bed has been used successfully for this purpose since July 2013. Operational results are presented for a six-year period between 2013 and 2018.

\section{SHIRLEY REEDBED BACKGROUND}

Shirley Landfill Site is located to the South West of the city of Birmingham, in the UK Midlands, and is the responsibility of Worcestershire County Council. The site was originally quarried for sand and gravel during the 1970s, and was restored between 1981 and 1988 by filling with 1.2 $\mathrm{Mm}^{3}$ of household wastes, over an area of 15 hectares. The average depth of the waste is about $8 \mathrm{~m}$ with a maximum of $12 \mathrm{~m}$ and a minimum of $3 \mathrm{~m}$.

$A$ reed bed at Shirley was designed and constructed during 2013, primarily to reduce concentrations of methane in leachate draining by gravity from the landfill, where it was recognised that uncontrolled inflow of groundwater was a significant contributor to leachate generation rates. Concentrations of dissolved methane being discharged to sewer were routinely exceeding a recently imposed limit of $0.14 \mathrm{mg} / \mathrm{l}$, and removal would take place by means of aerobic biological degradation, since methane is readily oxidised biologically by bacteria, in the presence of oxygen. Six years' data are available to demonstrate not only successful removal of methane (which is discussed in detail elsewhere; Robinson, H., 2017), but also provide valuable information on the limited and seasonal removal of ammoniacal- $\mathrm{N}$ being achieved by the bed.

\section{REEDBED DESIGN AND OPERATIONS}

\subsection{Reedbed Design Types}

Reedbeds are designed to pass flows of wastewater either horizontally (Figure 1), or vertically (Figure 2). Horizontal Flow Reed Beds (HFRBs) receive an inflow from an overflowing halfpipe structure at the inlet end of the bed,

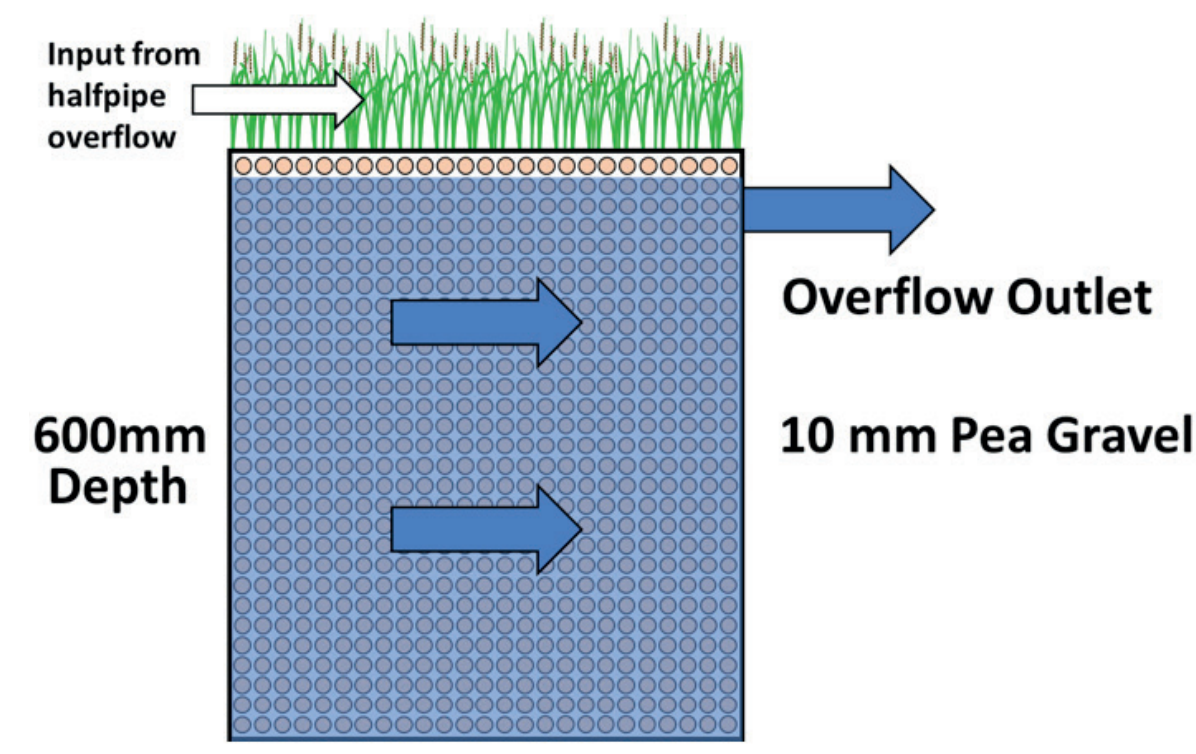

FIGURE 1: Cross-section of a horizontal flow reed bed (Robinson, T., 2018). 
Stage 1: No Flow, quiet phase

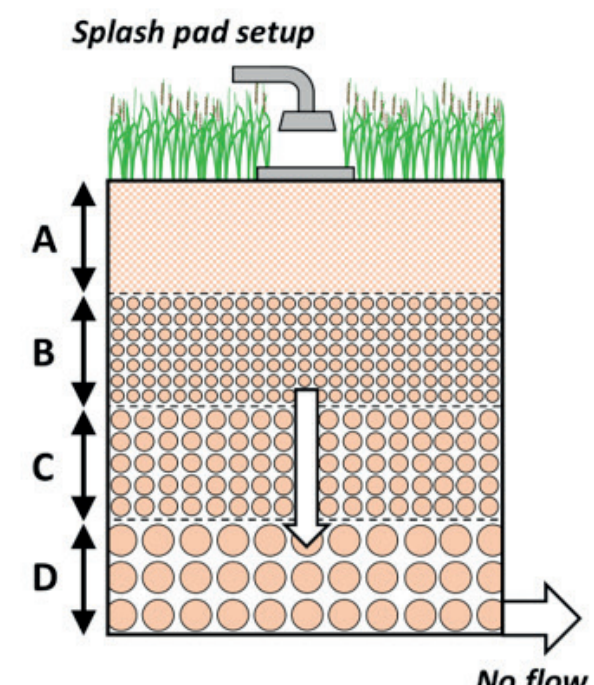

Stage 2: Reedbed flooded
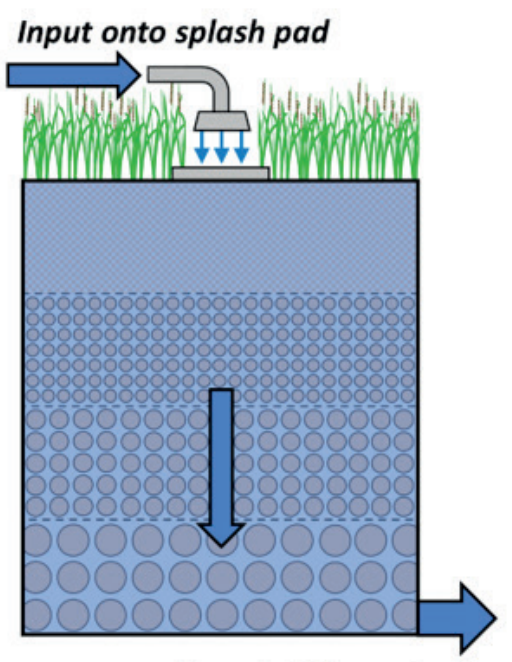

Free draining output
Stage 2: Reedbed drained

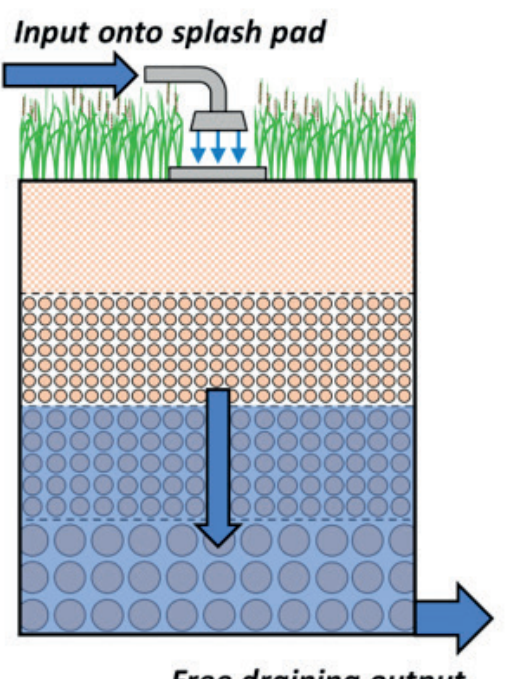

$A=$ Sharp Sand, B = 6mm Pea Gravel, C = 12 $\mathrm{mm}$ Round Gravel, $D=30-60 \mathrm{~mm}$ Round Stone

before the water flows across the flooded bed, at a depth predetermined by the height of the overflowing outlet. Single-size gravel media (typically $10 \mathrm{~mm}$ pea gravel) is generally flooded to just below the gravel surface, avoiding surface flows bypassing treatment, and allowing water to flow horizontally, at a steady rate.

In a Vertical Flow Reed Bed (VFRB), the media are a range of sizes, and water levels in the bed vary during treatment cycles. Incoming leachate, or pre-treated leachate, enters as occasional 'slug' doses, and floods the bed surface. The liquid gradually passes down through the bed, contacting oxygen in the spaces between the media. The bed becomes fully flooded, and effluent drains from the bottom of the bed. As the liquid drains out, fresh air, containing oxygen, is drawn down into the media of the bed. Eventually the bed drains completely, ready for another dose of feed. Vertical flow beds therefore have greater oxygen inputs, so can provide more treatment (e.g. nitrification of ammoniacal-N), but are usually not so good at solids removal (Robinson, T., 2018).

\subsection{Mechanisms for removal of other contaminants within reedbeds}

Although vertical flow reed beds have been reported to provide higher rates of removal of ammoniacal-N than horizontal flow beds, their reduced performance in achieving removal of solids, and the intrinsic simplicity of the horizontal bed, were key to the horizontal bed being selected at Shirley. Previous papers describe case studies of vertical flow reed bed systems (Robinson, T., 2017).

Iron (and suspended solids) are readily removed in a reed bed system, principally by oxidation and physical filtration processes. The rhizome system of the reeds within the gravel bed may contribute to improved performance, by enhancing the supply of oxygen, which is required to convert soluble iron (II) to insoluble iron hydroxide (III).

Although reed beds have a poor record for removal of ammoniacal nitrogen from effluents containing high levels of COD and BOD (for example, widely noted for direct treatment of domestic wastewaters), they are generally more successful in situations where concentrations of organic contaminants are much lower, (for example, biologically pre-treated leachates), and more oxygen is therefore available to nitrifying organisms, principally Nitrosomonas and Nitrobacter, which convert ammoniacal nitrogen to nitrite, and then to nitrate.

\section{DESIGN AND CONSTRUCTION OF THE SHIRLEY REEDBED}

The type of reed bed installed at Shirley is a lined, gravel-filled, horizontal flow bed. Reeds, Phragmites Australis, have been planted into the gravel at the site. Effluent enters at the inlet of the beds, travelling slowly through the bed following a horizontal flowpath, before flowing over a level control device within a chamber at the outlet end of the reed bed. Plate 1 below depicts the chamber containing the overflow point, at the end of the Shirley horizontal flow reed bed. This photograph shows the reed bed during its construction phase, when the bed was newly installed, and the reeds were freshly planted.

The reed bed at Shirley was constructed by Phoenix Engineering, during the first half of 2013. The design was based on flow information provided by the Council, which stated that mean flow rate would be about $50 \mathrm{~m}^{3} / \mathrm{d}$, and within a range from $24 \mathrm{~m}^{3} / \mathrm{d}$ to a maximum flow of $78 \mathrm{~m}^{3} / \mathrm{d}$. Leachate draining from the site is captured by a series of French drains and a pipeline that runs to a chamber within the site, before being discharged into the public sewer. On several occasions previously, the limit set by the discharge 


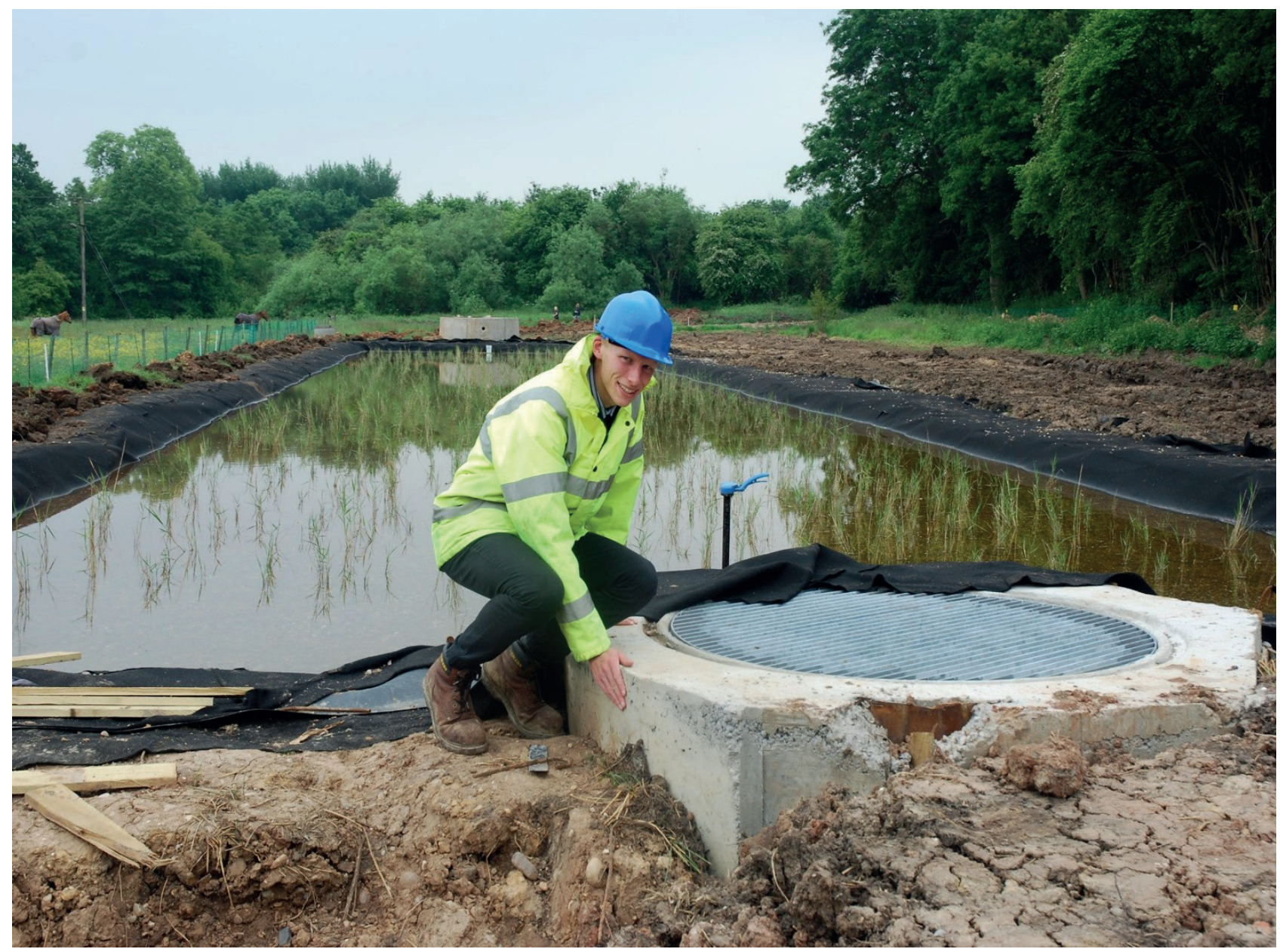

PLATE 1: The chamber at the outlet end of the Shirley Reed Bed during the construction phase of the reed bed

consent for dissolved methane was being exceeded, which had the potential to be hazardous.

It was recognised that uncontrolled inflow of groundwater into the landfilled wastes was a significant contributor to leachate generation rates. A reedbed was a far more sustainable and practical option for an unmanned, relatively remote, closed landfill site, than would have been provided by a mechanical methane stripping arrangement, and, although the development was in the green belt, it was recognised that the development was necessary to avoid pollution, and noted that the only alternative would have been to take leachate off-site in tankers, generating traffic and causing amenity impacts.

There was no means of buffering leachate flows from the landfill, as these arrived at the original manhole, from where flows to sewer were made, and the reed bed design did not seek to provide any additional leachate storage or flow buffering. Nevertheless, results indicated that although flow rates showed seasonal variation, they did not respond rapidly to rainfall events, as might be expected from a landfill where significant groundwater inflows were involved. Previous work had demonstrated a close link between general groundwater levels in the local aquifer, and leachate flow rates.

Leachate transfer arrangements required modification, with construction of a new deep chamber into which leachate would now drain from the site by gravity, and from where it would be pumped in a controlled way by duty/ standby pumps into a new surface-mounted precast concrete header tank, having a diameter of $2.4 \mathrm{~m}$ and a depth of $1 \mathrm{~m}$ (volume $5 \mathrm{~m}^{3}$ ). This header tank was designed to encourage the quiescent settlement and retention of any silt or precipitated iron solids, with supernatant leachate overflowing to the reed bed inlet.

The reed bed is contained by an engineered earth embankment, and has a length of $50 \mathrm{~m}$, a width of $7 \mathrm{~m}$, a gravel depth of $0.6 \mathrm{~m}$, and an estimated hydraulic volume of about $85 \mathrm{~m}^{3}$, giving an estimated mean hydraulic retention time (HRT) of between 1 and 2 days at anticipated flow rates. Effluent from the bed drains into a discharge chamber at its remote end, flowing over a variable level control mechanism, which in most circumstances maintains water level within the bed just below the gravel surface. Plate 2 gives an overview of the entire reedbed treatment system.

\section{ONGOING PERFORMANCE OF SHIRLEY REEDBED}

The Shirley reed bed has always performed successfully, removing all methane from leachate entering it, includ- 


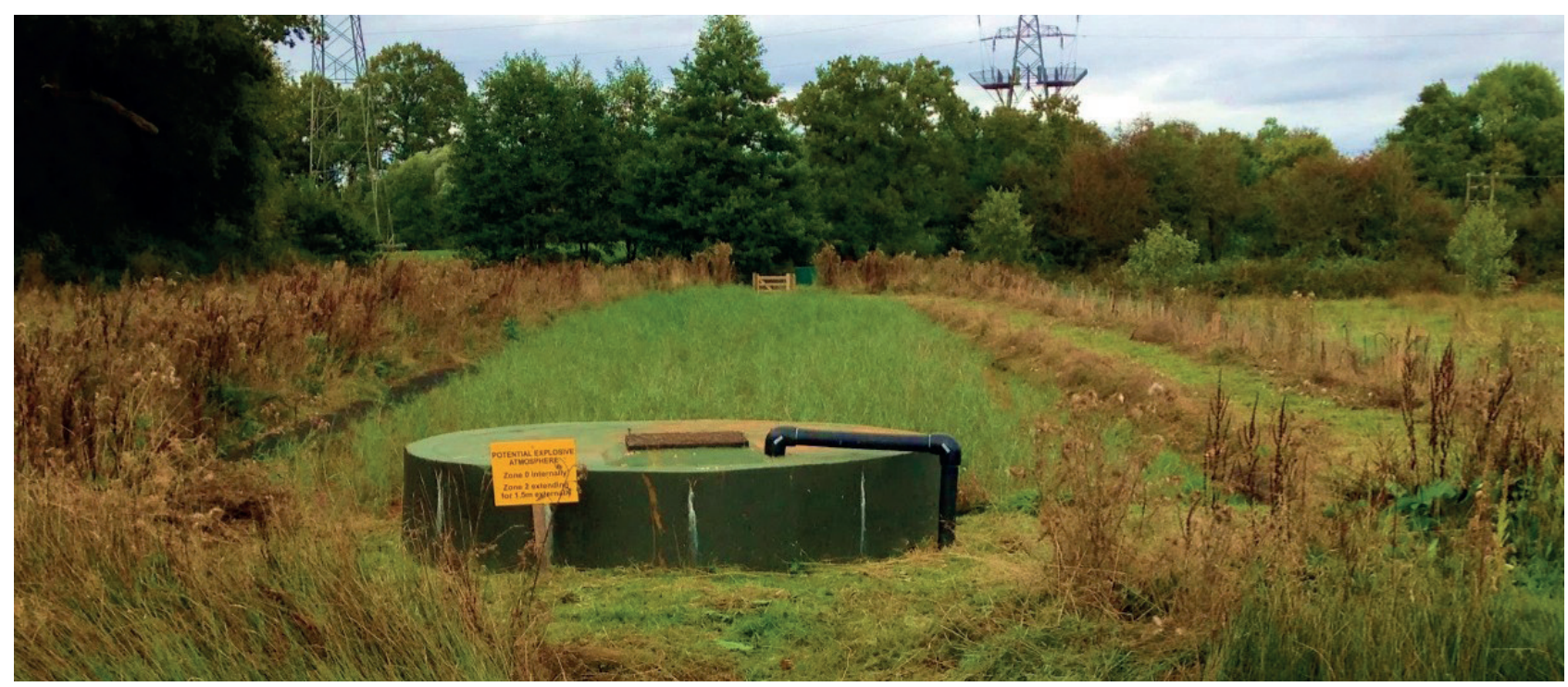

PLATE 2: General view of Shirley Reedbed from the inlet end, showing the Leachate Header Tank in the foreground, September 2014.

ing when flows were more than double design rates during early 2014. Since the bed was commissioned in July 2013, routine sampling of raw and treated leachates has been carried out regularly, and all flow meters and recording instruments have performed accurately and reliably. The collection of such detailed data has enabled the production and interpretation of the following figures, which highlight the success of the reed bed as a treatment method for removing methane, suspended solids, and some ammoniacal-N from the leachate.

\subsection{Operational data}

The most significant impact on operation of the bed, since it was commissioned, has been the flows of leachate passing through it, which have sometimes exceeded the original design specification. In particular, there were extreme and record-breaking levels of rainfall during the early months of 2014, with more than double average rainfall amounts during January and February. This led to the reed bed receiving and treating leachate flows as high as $160 \mathrm{~m}^{3} / \mathrm{d}$, with highest values recorded during late February/early March 2014 (see Figure 3).

During the full year from 1 October 2013 to 30 September 2014, mean leachate flow rate was just over $65 \mathrm{~m}^{3} / \mathrm{d}$ - 30 per cent greater than predicted values, and the maximum flow rate of $163 \mathrm{~m}^{3} / \mathrm{d}$ was more than double the anticipated maximum flow rate of $78 \mathrm{~m}^{3} / \mathrm{d}$.

During the first 3 months of 2014 , more than $10,000 \mathrm{~m}^{3}$

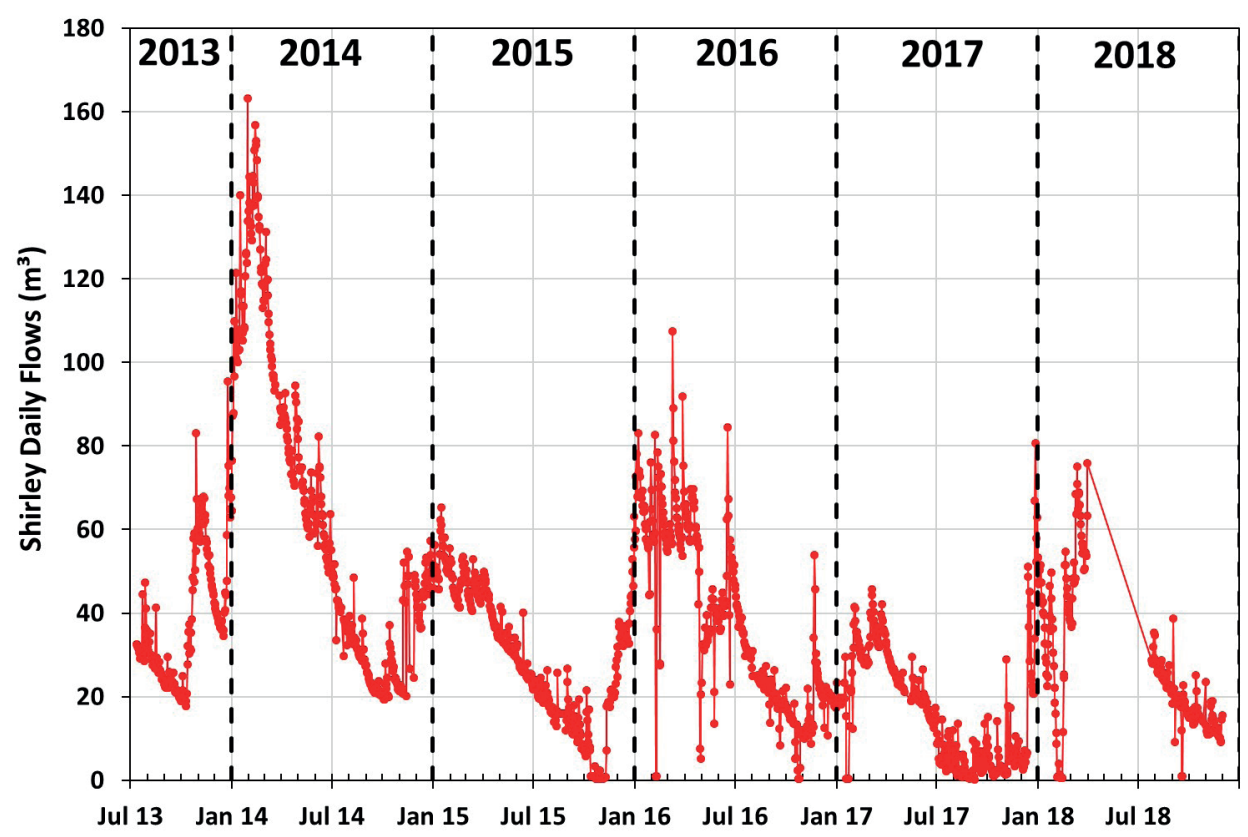

FIGURE 3: Daily volumes treated at Shirley, July 2013 to December 2018 (in $\mathrm{m}^{3} / \mathrm{d}$ ). 
of leachate passed through the bed $\left(10,348 \mathrm{~m}^{3}\right)$, at a mean flow rate of $115 \mathrm{~m}^{3} / \mathrm{d}$, with a maximum monthly flow of $3,766 \mathrm{~m}^{3}$ during February 2014 (mean rate $134.5 \mathrm{~m}^{3} / \mathrm{d}$ ); 45 per cent greater than predicted maximum instantaneous flow rates, throughout the month.

Figure 3 highlights the very seasonal nature of the flow rates passing through the reed bed, whereby typical daily flows during winter months (excluding the winter of 2013/14) can be elevated above $60 \mathrm{~m}^{3} /$ day, whilst in summer and autumn months, the flows can reduce to below 20 $\mathrm{m}^{3} /$ day.

\subsection{Treatment requirements and assessment of treatment efficiency}

Table 1 presents the criteria for the discharge consent, as set by Severn Trent Water plc, for discharges of effluent from the Shirley Reed Bed. The maximum volume of effluent that was to be discharged to sewer, as agreed with Severn Trent Water, was set at $137 \mathrm{~m}^{3}$ during any single 24-hour period.

Results comparing concentrations of various contam-

TABLE 1: Discharge conditions set by Severn Trent Water Limited on 14th August 2014, for wastewaters being discharged into the Upper Cole Valley Sewer.

\begin{tabular}{c:ccc}
\hline Condition / Determinand & Units & Discharge consent \\
\hline Maximum Discharge Rate & $\mathrm{l} / \mathrm{sec}$ & 2 \\
\hline Dissolved Methane & $\mathrm{mg} / \mathrm{l}$ & $<0.14$ \\
\hline $\mathrm{pH}$ value & $\mathrm{pH}-\mathrm{Value}$ & $>6 \mathrm{and}<10$ \\
$\mathrm{COD}$ & $\mathrm{mg} / \mathrm{l}$ & 300 \\
\hline Ammoniacal-N & $\mathrm{mg} / \mathrm{l}$ & 50 \\
\hline Phosphorus & $\mathrm{mg} / \mathrm{l}$ & 25 \\
\hline Suspended solids & $\mathrm{mg} / \mathrm{l}$ & 200 \\
\hline
\end{tabular}

inants in incoming leachate flows are compared with values determined in treated leachate discharged to sewer, in Figures 4 to 11 .

The effects of dilution during passage through the bed due to rainfall, or possible concentration from evapotranspiration losses, were determined by observation of concentrations of the two conservative ions sodium and chloride, which are not affected by any treatment processes of the reed bed. Results for sodium and chloride in raw and treated leachate are presented below in Figures 4 and 5 respectively.

Sodium and chloride results confirm that no significant dilution or concentration of contaminants took place during passage of leachate through the reed bed, which means that changes in concentrations of other contaminants can be entirely attributed to treatment being provided by biological and chemical changes taking place within the bed.

Also of interest is the fact that although flow rates of leachate from Shirley Landfill, and therefore rates of leachate flow through the bed, increased substantially during early 2014, this was not associated with equivalent dilution of the leachate being received for treatment. This is characteristic of landfills where high proportions of leachate being produced are derived from groundwater inflows.

\subsection{Removal of methane concentrations}

Figure 6 demonstrates that from the date that the reed bed began to receive leachate, on 12 July 2013, until the end of March 2014, all dissolved methane was removed completely, including during the periods of greatest flow. Even during those periods, concentrations of dissolved methane regularly exceeded $1 \mathrm{mg} / \mathrm{l}$ in the incoming leachate flows.

From April 2014 to mid-June 2014, as flows reduced gradually from peak values of $160 \mathrm{~m}^{3} / \mathrm{d}$ in early 2014 (dou-

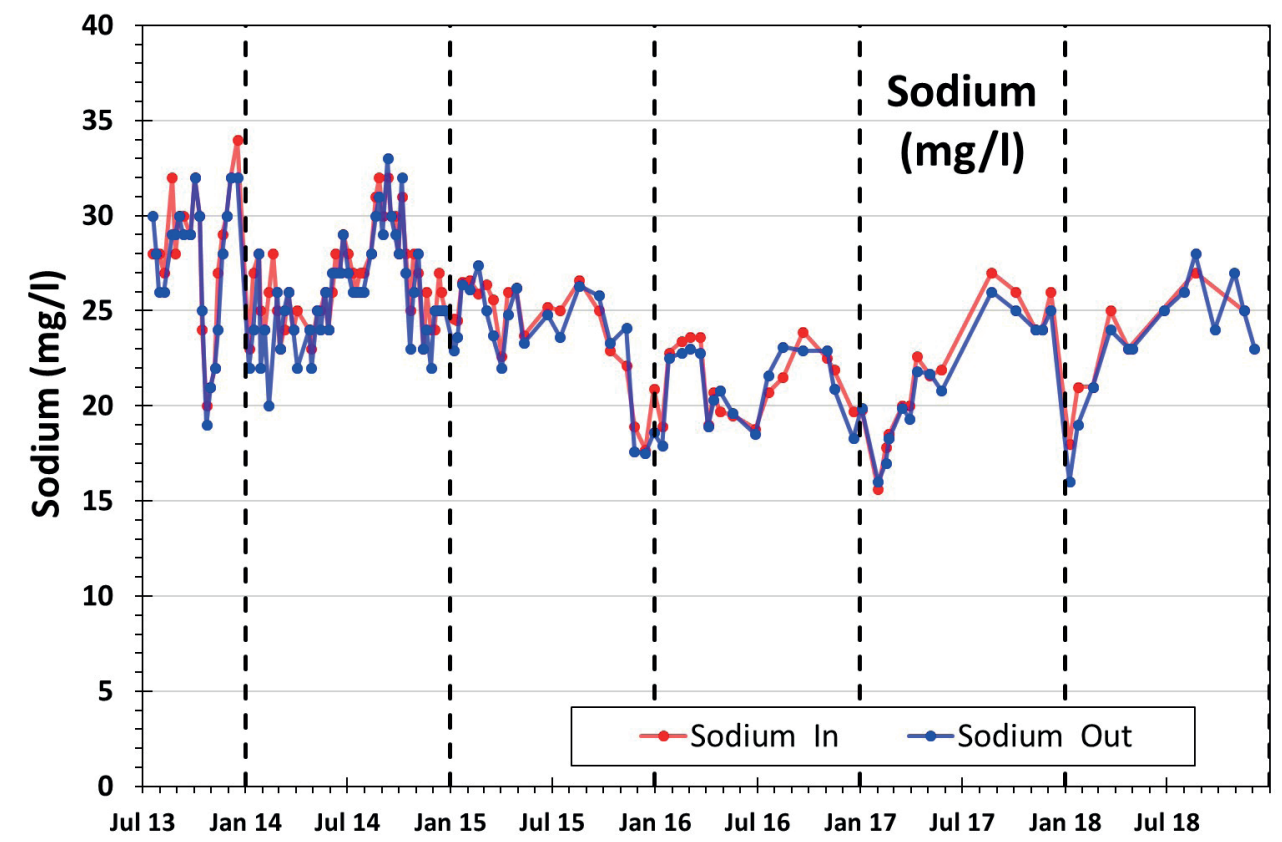

FIGURE 4: Variation in concentrations of sodium during passage through the reedbed, July 2013 to December 2018 (all results in mg/l as sodium). 


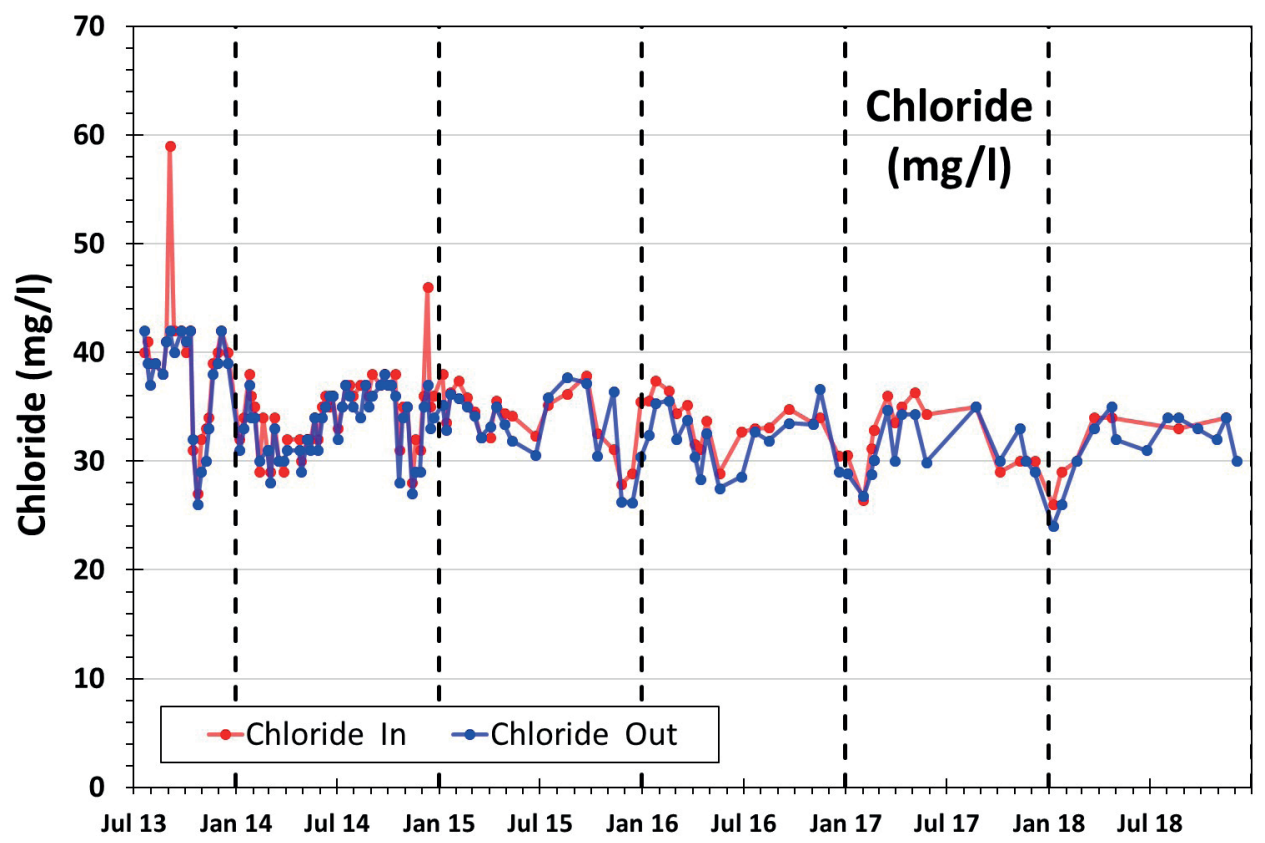

FIGURE 5: Variation in concentrations of chloride during passage through the reedbed, July 2013 to December 2018 (all results in mg/l as chloride).

ble the maximum design values), concentrations of dissolved methane in raw leachate rose significantly, reaching a peak value of $3.75 \mathrm{mg} / \mathrm{l}$ in mid-May 2014. During this period, low levels of dissolved methane were measured in treated leachate, which rose to a maximum value of 0.7 mg/l during July 2014, when raw leachate contained about $3.5 \mathrm{mg} / \mathrm{l}$ of dissolved methane (also nearly twice design values), at flow rates of 40 to $50 \mathrm{~m}^{3} / \mathrm{d}$.

The very high flow rates also had an effect of flushing out quantities of iron from within the landfill drainage sys- tem, some of which reached the surface of the bed near to the inlet, and had to be removed by works during July 2014. Although concentrations of dissolved methane in raw leachate remained above $2 \mathrm{mg} / \mathrm{l}$, as leachate flow rates gradually declined towards $20 \mathrm{~m}^{3} / \mathrm{d}$ by the end of September 2014 , dissolved methane in effluent returned to below the consent limit of $0.14 \mathrm{mg} / \mathrm{l}$ during August 2014 .

Since August 2014, the reed bed has always achieved consistent removal of methane down to below the consent limit of $0.14 \mathrm{mg} / \mathrm{l}$. Figure 6 shows that even after increased

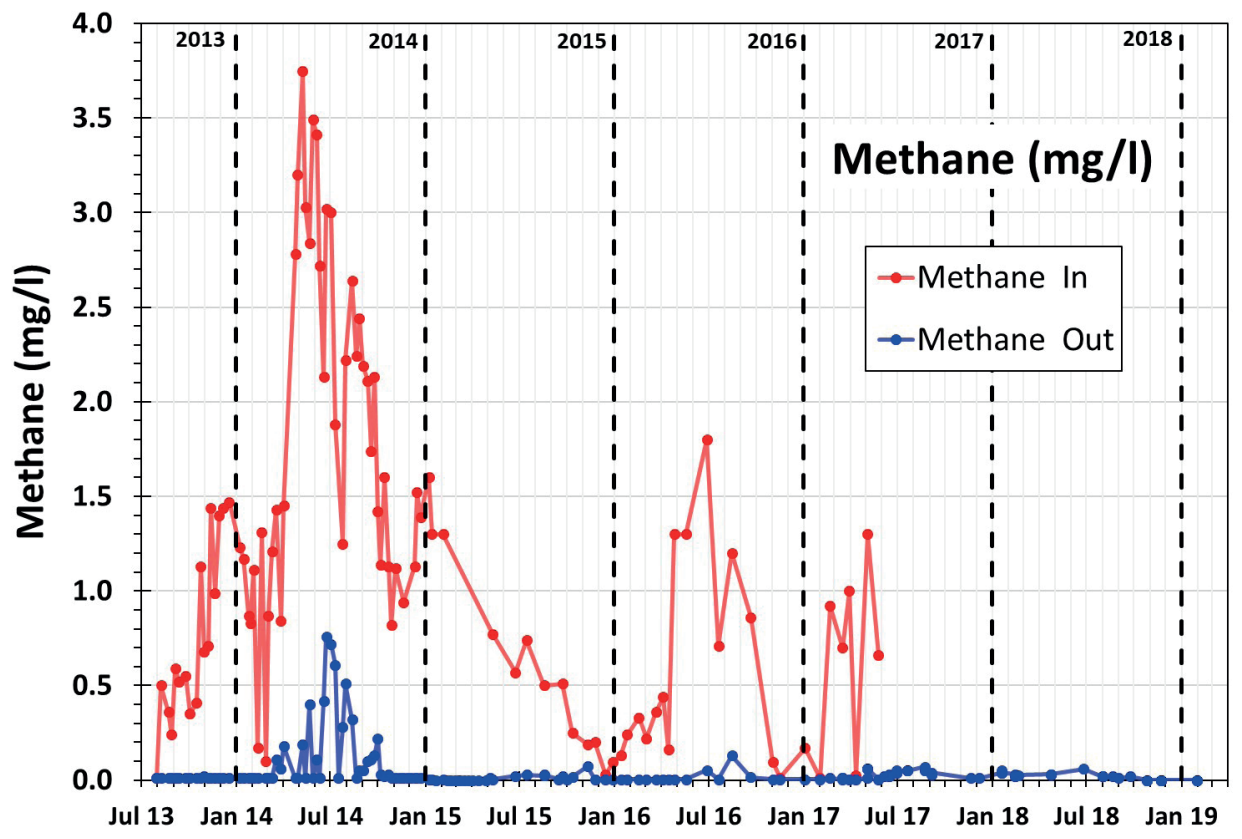

FIGURE 6: Concentrations of methane in raw leachate and following reedbed treatment, between July 2013 to January 2019 (all results in $\mathrm{mg} / \mathrm{l}$ of methane). 
flows following high rainfall during the winter of 2015/16, the methane concentrations within the effluent from the reed bed remained below the consented level.

Figure 7 presents the trends for methane and ammoniacal-N removal rates. This graph highlights that the reed bed is able to provide increased removal of methane when required, during periods of increased leachate flows passing through the reedbed.

Figure 8 displays data for both ammoniacal- $\mathrm{N}$ and methane loads that have been experienced by the reed bed between July 2013 and November 2018. It is evident from this figure that periods of increased ammoniacal- $\mathrm{N}$ and methane loading are experienced when higher volumes of leachate are being passed through the reed bed. Following the exceedingly high volumes of leachate that were experienced at the reed bed during winter 2013/2014 (mean monthly rates of up to $134.5 \mathrm{~m}^{3} / \mathrm{d}$ ), seasonal loading rates were much lower and more consistent during following years.

During summer 2017, it was decided that methane concentrations within the raw leachate would no longer be analysed. Instead, only the treated effluent methane con-

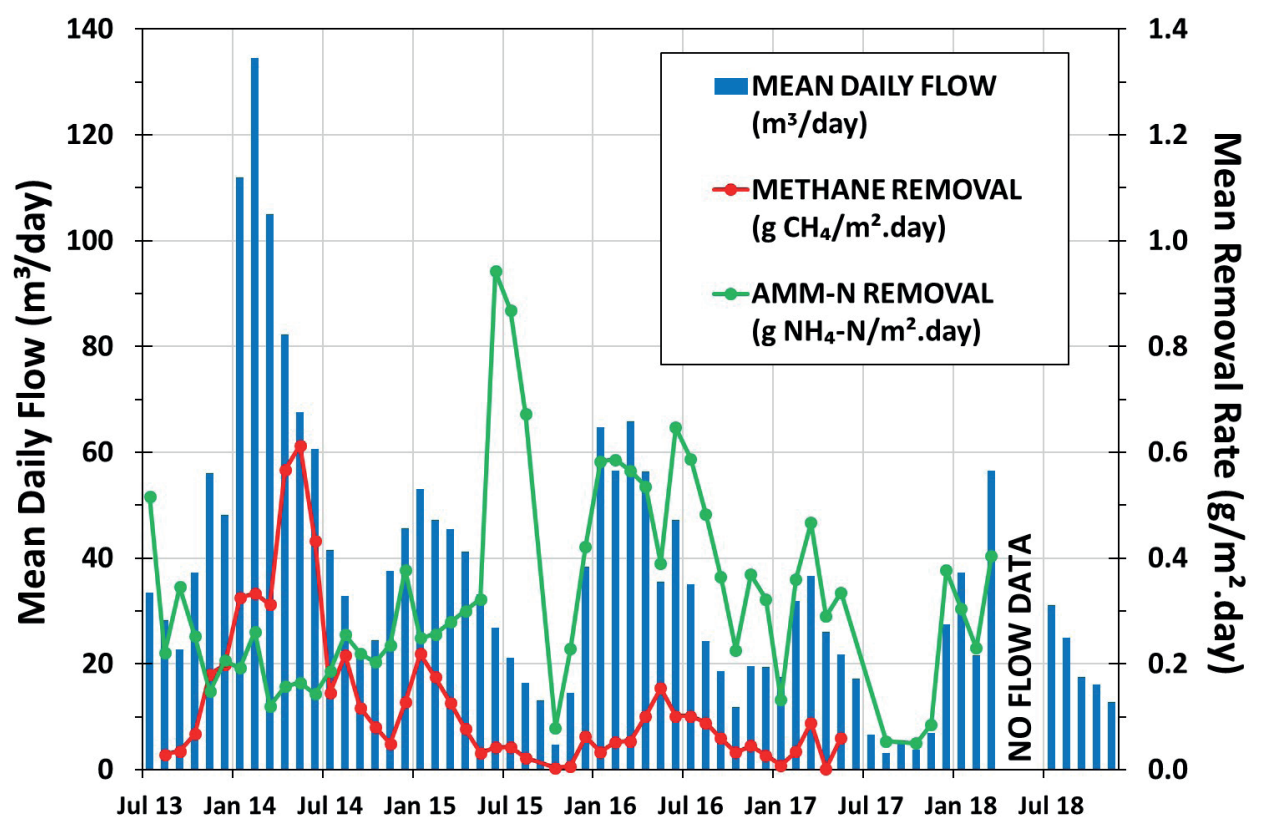

FIGURE 7: Removal rates for ammoniacal-N and methane, compared to the variations in flow rates through the Shirley reed bed system. July 2013 to November 2018.

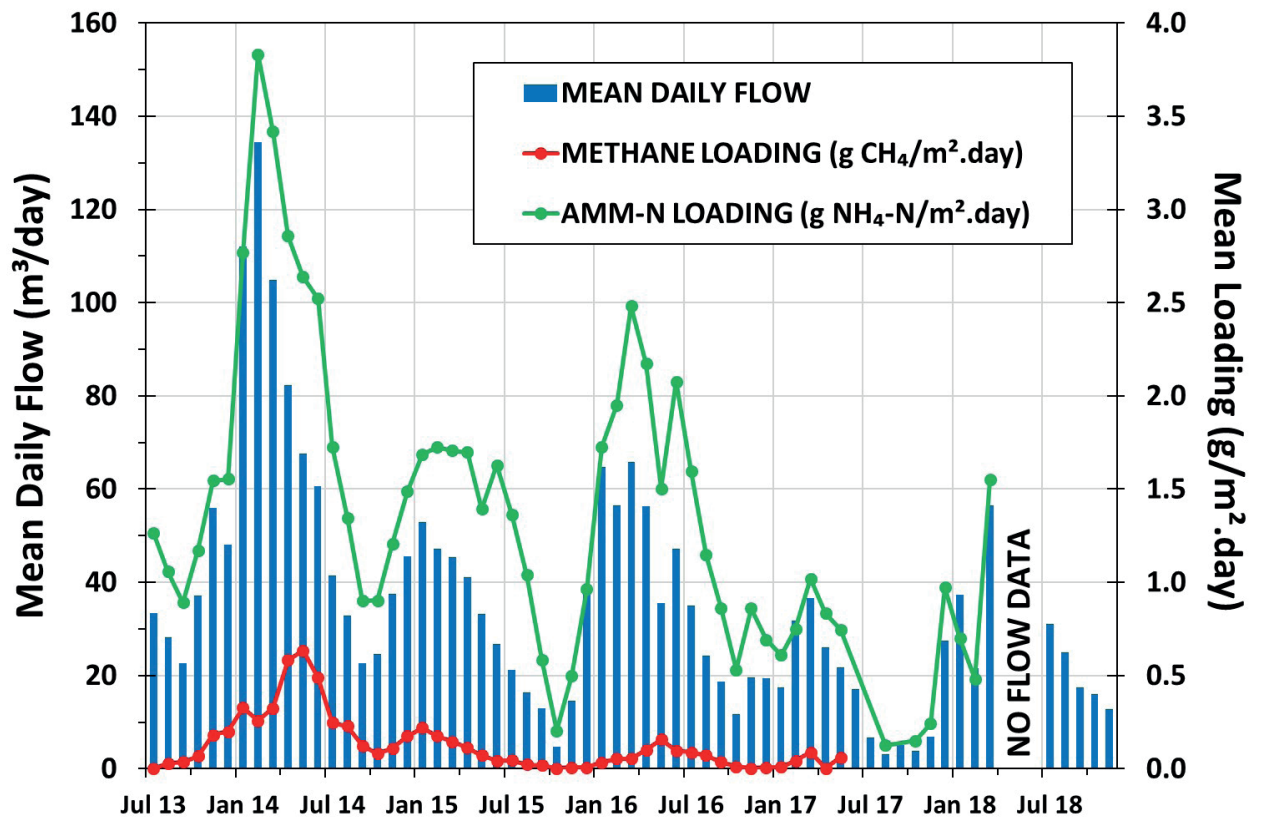

FIGURE 8: Ammoniacal-N and methane loading, compared to the variations in flow rates through the Shirley reed bed system. July 2013 to November 2018. 
centrations would be observed. This highlights how successful the system has been, and the fact that the client at Worcestershire County Council is confident in the process reducing methane concentrations within the raw leachate, down to a level below the $0.14 \mathrm{mg} / \mathrm{l}$ consent. Because of the decreasing concentrations of methane within the leachate, it was predicted that methane concentrations would not exceed 1.5mg/l, from May 2017 onwards.

Because methane samples have not been taken and analysed after May 2017, Figure 7 and Figure 8 do not display data for methane removal or methane loading rates after this date.

\subsection{Treatment of other contaminants}

Reed bed performance in terms of removal of other contaminants is discussed below. Figure 9 examines changes in COD values through the bed, which have been minimal. Figure 9 shows that influent COD is not impacted by changes in rainfall or seasonal flows, and highlights the overall mean leachate COD concentration of $22.8 \mathrm{mg} / \mathrm{l}$ is very similar to the effluent concentration of $20.3 \mathrm{mg} / \mathrm{l}$.

Figure 10 presents results for ammoniacal-N in raw and treated leachates, which demonstrates that (i) there is significant removal of ammoniacal-N, and (ii) ammoniacal-N removal rates are greatest during warmer months, when loadings are reduced (Figure 8). Although concentrations of ammoniacal-N were lower during the period October 2013 to May 2014 (typically between $8 \mathrm{mg} / \mathrm{l}$ and $11 \mathrm{mg} / \mathrm{l}$ ), removal rates were minimal ( $<10$ per cent), due at least in part to the very high flow rates during this period.

However, during warmer months of each year, when flow rates were also reduced, although ammoniacal- $\mathrm{N}$ was typically present at between $12 \mathrm{mg} / \mathrm{l}$ and $14 \mathrm{mg} / \mathrm{l}$, removal rates of up to 50 per cent were achieved during the period July to September 2013, and again during the summer periods of all following years. At slightly greater flow rates during summer 2014, ammoniacal-N removal rates of up to 25 or 30 per cent were still achieved.

Removal of ammoniacal-N was not any part of the specific design of the reed bed at Shirley, but is clearly being achieved to a significant extent during warmer summer months at the following rates:

- Summer: 0.6 to $1.0 \mathrm{gN} / \mathrm{m}^{2}$.day

- Winter: 0.4 to $0.5 \mathrm{gN} / \mathrm{m}^{2}$.day

\subsection{Removal of iron concentrations}

Figure 11 presents results for concentrations of iron during passage through the reed bed. These results suggest that very little iron is present in incoming raw leachate $(<0.1 \mathrm{mg} / \mathrm{l})$ throughout the period from October 2013 to September 2014. We know that this is not the case, and observation demonstrates significant accumulation of iron oxides and hydroxides as rust-like deposits across the surface of the bed at the inlet end, and to a lesser extent across the entire bed (Robinson et.al, 2015).

The reason that very low iron concentrations were being determined and reported in raw leachates prior to September 2014, was that these samples were being filtered by the laboratory before being tested for iron. Following September 2014, all iron results have been determined on unfiltered samples, to provide more accurate data.

Although high levels of iron-rich sludge deposits accumulated at the inflowing end of the reed bed during the winter of 2014, the outlet end of the reed bed remained clear of these deposits (Plate 3 ). The high levels of sludge that did reside at the inlet end of the reed bed were easily removed by manual clearing of the surface of the reedbed in the affected areas. This clearing process of the reed bed is not expected to be a regular operation, and in this instance was only necessary following the extreme flow rates after the heavy rainfall experienced during the winter of 2013/14.

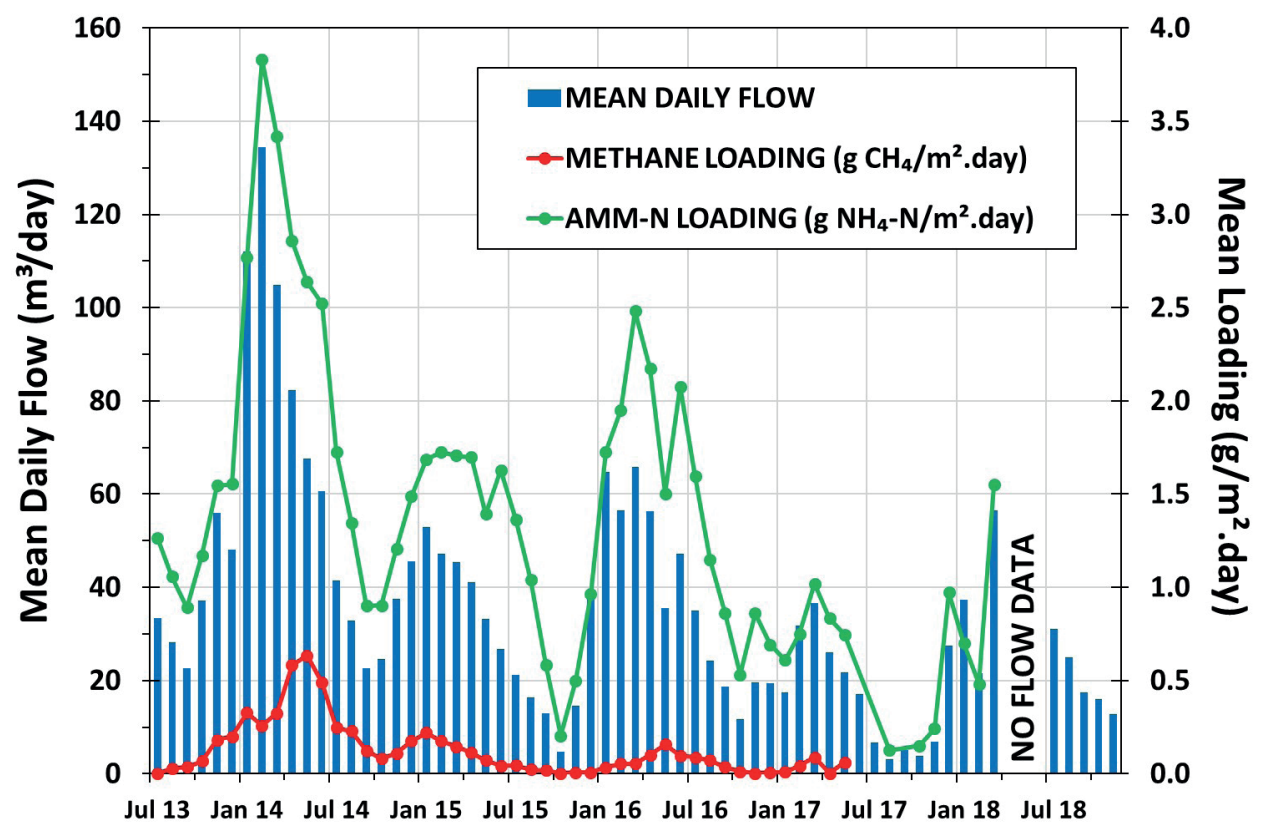

FIGURE 9: Variation in COD values during passage through the reedbed, July 2013 to December 2018 (all results in mg/l of COD). 


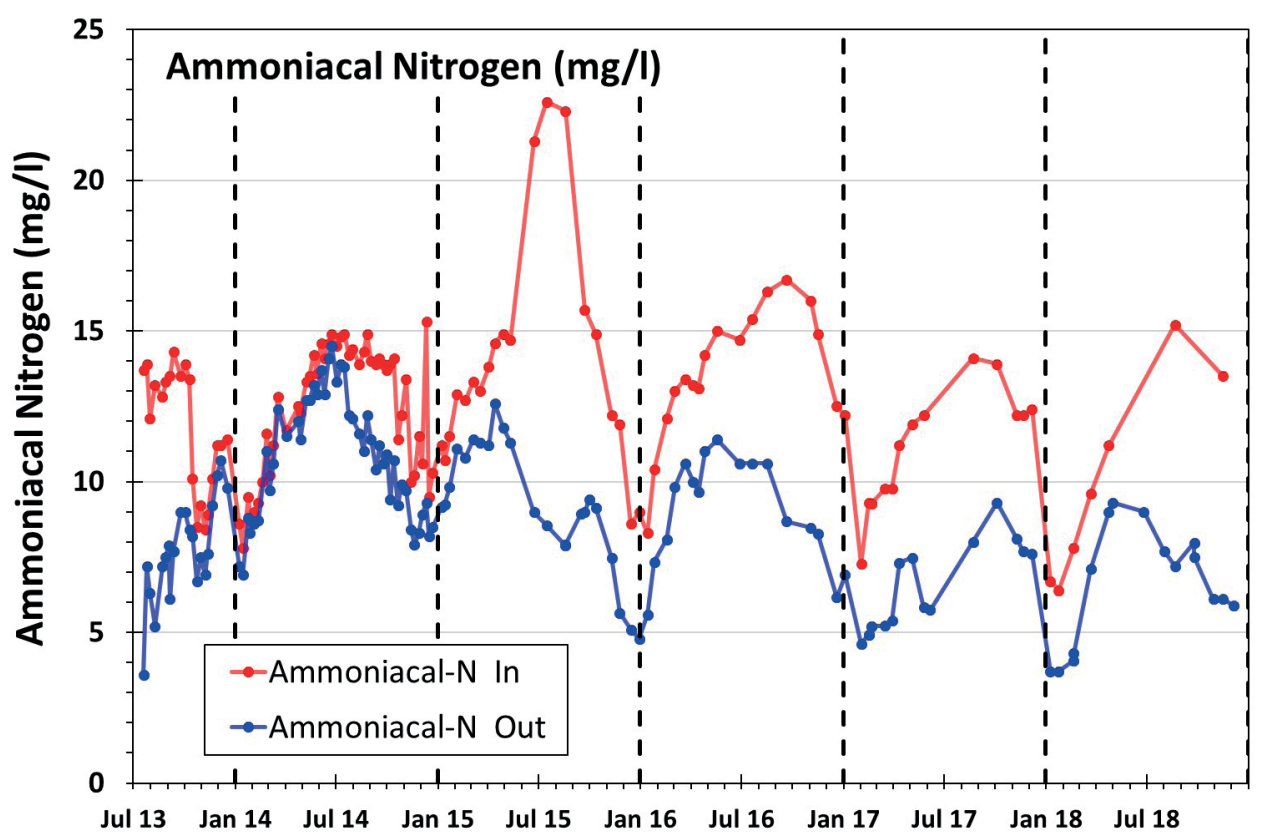

FIGURE 10: Variation in concentrations of ammoniacal-N during passage through the reedbed, July 2013 to December 2018 (all results in $\mathrm{mg} / \mathrm{l}$ as $\mathrm{N}$ ).

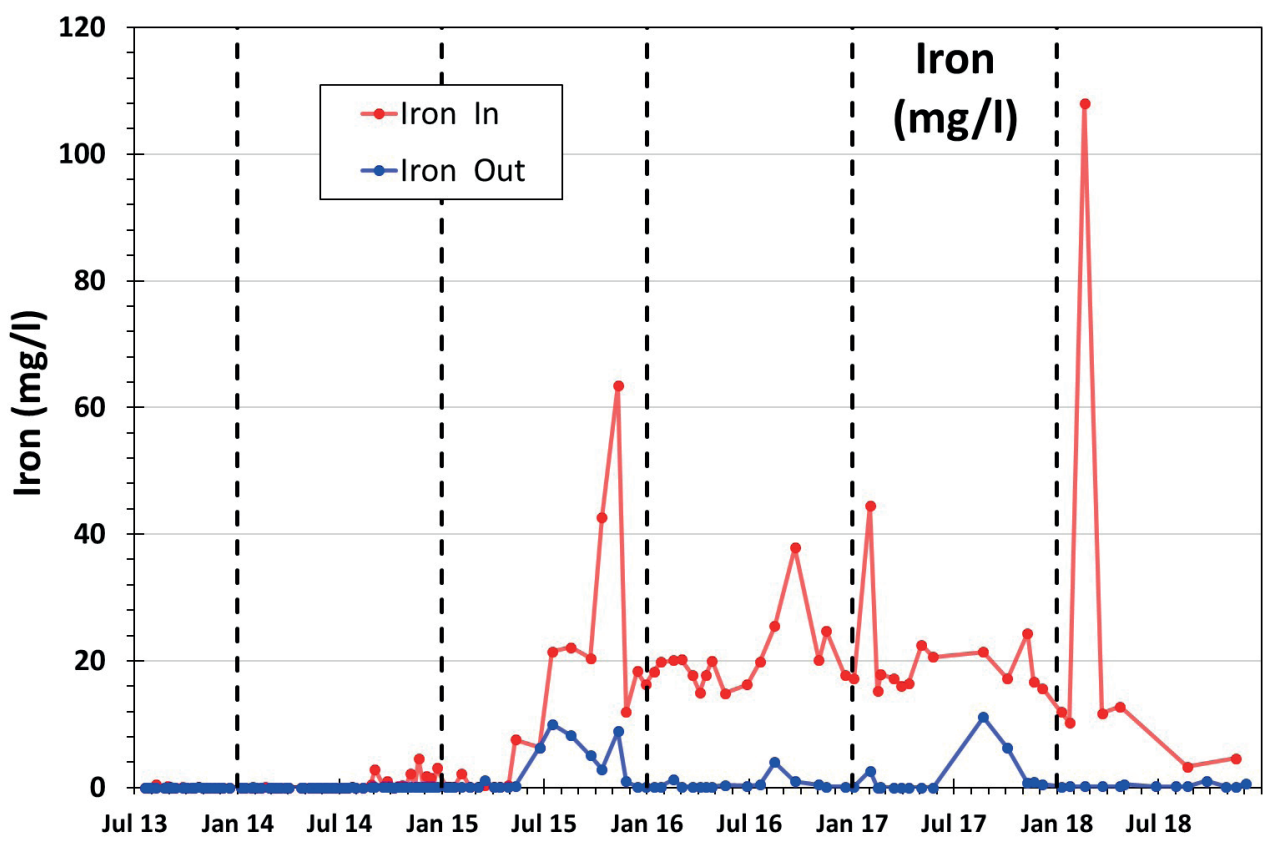

FIGURE 11: Variation in removal rates of iron following passage of leachate through the reed bed (all results in $\mathrm{mg} / \mathrm{l}$ ).

\section{RESULTS AND DISCUSSION}

The Shirley reed bed has performed well since commissioning during 2013, removing all methane from leachate entering it, achieving successful removal even when flows were more than double design rates during early 2014 . The reed bed is very successful at removing high initial levels of dissolved methane ( $95 \%$ removal), as per the intended requirements. This ensures that methane remains well below the $0.14 \mathrm{mg} / \mathrm{l}$ discharge consent.

As presented in Figure 8, the loading rate for methane into the reed bed has gradually reduced over time, allowing complete removal to be achieved. This is as a result of lower concentrations of methane within the incoming leachate from Shirley landfill in recent years. Figure 7 shows that when, in 2014 the methane concentration within the leachate was greater than $3 \mathrm{mg} / \mathrm{l}$, and the daily flow of leachate was above $80 \mathrm{~m}^{3} /$ day, methane removal rates exceeded $0.6 \mathrm{~g} \mathrm{CH}_{4} / \mathrm{m}^{2} / \mathrm{d}$. During 2015 and 2016, maximum removal rates peaked at $0.2 \mathrm{~g} \mathrm{CH}_{4} / \mathrm{m}^{2} / \mathrm{d}$, when methane concentrations were between $1 \mathrm{mg} / \mathrm{l}$ and $2 \mathrm{mg} / \mathrm{l}$, during periods when incoming leachate flow rates were between 40 


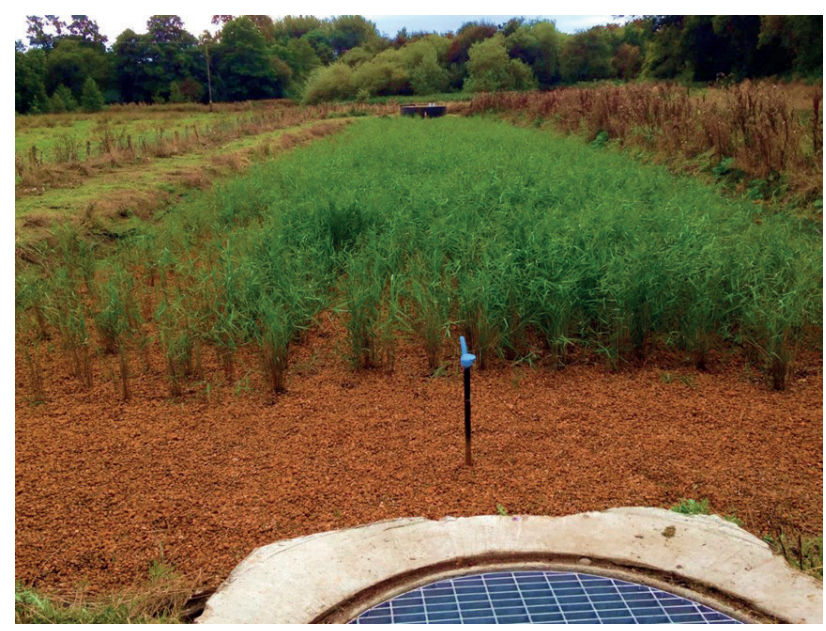

PLATE 3: Outlet end of the reed bed at Shirley during July 2014, showing very clean gravel and good reed growth.

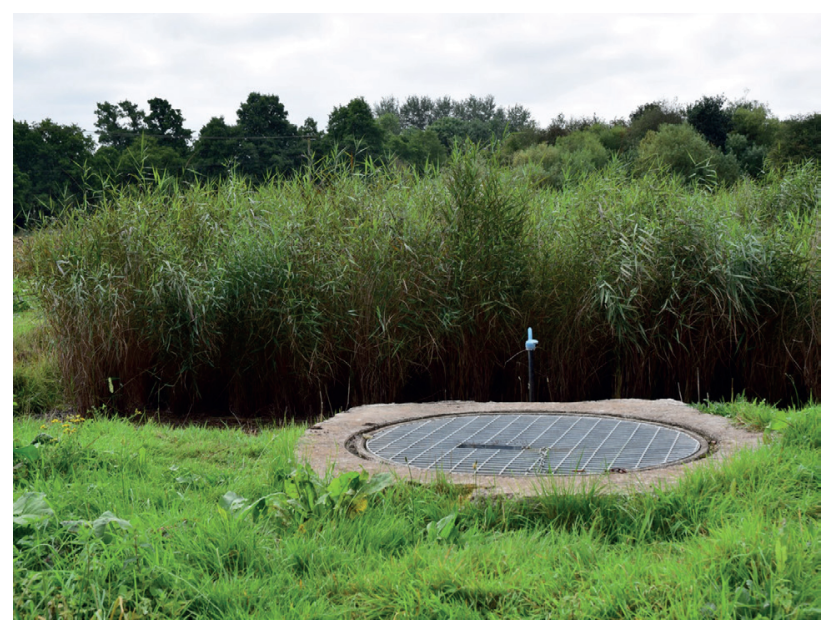

PLATE 4: Outlet end of the reed bed at Shirley during Summer 2016, showing excellent reed growth.

and $70 \mathrm{~m}^{3} /$ day. Because of the gradual reduction in methane production by the landfill, it has been determined that the methane concentrations within the incoming leachate have remained lower than $1.5 \mathrm{mg} / \mathrm{l}$ ever since 2017 . Therefore, it has not been necessary for the methane removal rate to exceed $0.1 \mathrm{~g} \mathrm{CH}_{4} / \mathrm{m}^{2} / \mathrm{d}$, for complete removal to be maintained.

Because the reed bed has been removing methane so reliably for more than six years, Worcestershire County Council have decided that they no longer require analytical data for methane concentrations within the raw leachate. The council are satisfied to observe the methane concentrations within the outflowing effluent from the overflow discharge chamber at the end of the reed bed, which consistently removes methane to below the $0.14 \mathrm{mg} / \mathrm{l}$ discharge consent.

Seasonal removal of ammoniacal-N has taken place within the reed bed (up to 50 percent removal between 2013 and 2018), but this was not part of the design purpose of the bed. Nevertheless, as more data are obtained, it will be possible to obtain useful loading rate data for this removal.

Figure 7 demonstrates that removal rates of ammoniacal- $\mathrm{N}$ through the reed bed exceeded $0.9 \mathrm{~g} \mathrm{NH}_{4}-\mathrm{N} / \mathrm{m}^{2} / \mathrm{d}$ during the summer of 2015 , when raw leachate concentrations were between $20 \mathrm{mg} / \mathrm{l}$ and $25 \mathrm{mg} / \mathrm{l}$. During following summer periods, maximum concentrations of ammoniacal-N within raw leachate were closer to $15 \mathrm{mg} / \mathrm{l}$, whilst removal rates peaked at $0.64 \mathrm{~g} \mathrm{NH}_{4}-\mathrm{N} / \mathrm{m}^{2} / \mathrm{d}$ during 2016, $0.47 \mathrm{~g} \mathrm{NH}_{4}-\mathrm{N} / \mathrm{m}^{2} / \mathrm{d}$ during 2017 , and $0.4 \mathrm{~g} \mathrm{NH}_{4}-\mathrm{N} / \mathrm{m}^{2} / \mathrm{d}$ during 2018. This gradual reduction in ammoniacal- $\mathrm{N}$ removal rate is due to the reduced flow rates of leachate through the red bed since 2016 .

The reed bed has performed very well indeed, although extreme rainfall conditions during early 2014 caused flows of up to $160 \mathrm{~m}^{3} / \mathrm{d}$ that were more than double maximum design values. Later in that year, concentrations of dissolved methane in the leachate reached 3.8 $\mathrm{mg} / \mathrm{l}$. This is nearly twice the reed bed design value of $2 \mathrm{mg} / \mathrm{l}$, and breakthrough of methane within the effluent to levels of $0.7 \mathrm{mg} / \mathrm{l}$ was noted for a short period, until methane levels in leachate returned to $2 \mathrm{mg} / \mathrm{l}$. Methane within the final effluent produced by the Shirley reed bed has consistently achieved the discharge consent set by the Environment Agency since this period in 2014, even when flow rates through the reedbed have exceeded the design parameters.

\section{CONCLUSIONS}

The Shirley reedbed treatment system demonstrates that a well-designed, constructed and operated plant is able to operate consistently, reliably, and cost-effectively, to meet stringent effluent discharge standards for dissolved methane at all times. The landfill owner has found the passive reed bed system to be cost-effective compared with other options such as tankering or methane stripping. The detailed operating data that this paper provides should give great confidence to both treatment plant operators, and to landfill regulators.

The reed bed continues to perform well, removing all methane from leachate entering it, following a brief period when flows were more than double design rates during early 2014. However, when concentrations of dissolved methane reached $3.5 \mathrm{mg} / \mathrm{l}$, almost double design assumptions, later in the year, some dissolved methane was detected in treated leachate, with a maximum concentration of 0.7 $\mathrm{mg} / \mathrm{l}$ recorded in early July 2014 . As methane levels fell below $2.0 \mathrm{mg} / \mathrm{l}$, essentially complete removal was again achieved.

This successful removal of methane has been achieved consistently for more than 5 years since summer 2014 and has continued through to the time of writing (summer 2019), despite the occasional increase in flow rates above the design capacity for the reed bed.

Some seasonal removal of ammoniacal-N continues to take place through the reed bed, however this was not part of the design purpose of the reed bed. Nevertheless, as more data are obtained, it will be possible to obtain further useful loading rate data for this removal. 
Removal of iron, and potential accumulation of iron within the bed over the longer term, are being monitored. It is likely that a high proportion of that iron which has entered the bed to date comprises iron dislodged from the landfill drainage system during extreme rainfall events in early 2014 . Some modifications to the raw leachate header tank arrangements are being considered, including introduction of compressed air into the pipeline transferring raw leachate into it, to encourage better oxidation and settlement of the iron within it. Prevention of iron accumulation in the bed by use of a header tank settlement arrangement has been implemented, and the reed bed design adopted at Shirley has great potential for adoption at many similar old and closed landfill sites.

\section{AKNOWLEDGEMENTS}

The author gratefully acknowledges the support of Worcestershire County Council throughout work on this project, and in the preparation of this paper. In particular, the assistance of Matthew Reed and Kristy Thomas has been invaluable.

\section{REFERENCES}

Hatamoto, M., Yamamoto, M., Kindaichi, T., Ozaki, N., and Ohashi, A. (2010). Biological oxidation of dissolved methane in effluents from anaerobic reactors using a down-flow hanging sponge reactor. Water Research, Volume 44, (5), March 2010, 1409-1418.

Novella, P., Haider, S., Strachan L., Robinson H. and Last S. (2004). Fullscale landfill leachate treatment in South Africa: the use of aerobic SBR processes and reed bed systems. Paper presented to WasteCon 2004, the biennial International Waste Congress and Exhibition of the Institute of Waste Management of Southern Africa, 11-15 October 2004, Sun City, South Africa. In the Proceedings of the congress, $11 \mathrm{pp}$.

Robinson H. (1993). The treatment of landfill leachates using reed bed systems. Paper presented to 'Sardinia '93', Fourth International Landfill Symposium, S. Margherita di Pula, Sardinia, Italy, 11-15 October 1993, In : Proceedings, Volume I, 907-922.

Robinson H. (1999). Methane stripping plant removes 99 percent plus at closed site. Local Authority Waste and Environment, July 1999, 7 , issue 7 , page 7 .
Robinson H., Harris G. and Last S. (1999). The stripping of dissolved methane from landfill leachates prior to their discharges into sewers. Paper presented to "Sardinia '99", the Seventh International Waste Management and Landfill Symposium, held in S. Marguerita de Pula, Cagliari, Sardinia, Italy, 4-8 October, 1999. In, Proceedings, Volume 2, 285-293.

Robinson, H., Walsh, T. and Carville, M. (2003). Advanced leachate treatment at Buckden landfill, Huntingdon, UK. Journal of Environmental Engineering and Science, National Research Council, Canada, 2, (4), 255-264, July 2003.

Robinson H. and Olufsen S. (2007). Full biological treatment of landfill leachate: a detailed case study at Efford Landfill, in the New Forest, Hampshire (UK). Paper presented to Sardinia 2007, the 11th International Waste Management and Landfill Symposium, held at Forte Village, S. Margherita di Pula, Cagliari, Italy, 1-5 October 2007, In, proceedings page 203 and on CDROM.

Robinson H., Harris G. and Truscott, S. (2008). Use of reed-bed systems to provide environmentally-friendly control of leachate from old landfills: Ten years of experience from a site in Wiltshire. Paper presented to Torbay 2006, The Annual Conference and Exhibition of CIWM, "Changing the Face of Waste Management", Paignton, June 2006. Published in Communications in Waste and Resource Management, March 2008, 9, (1), pp 31-41.

Robinson, H., Olufsen, J.S., Thomas, K., Reed, M., Robinson, T. (2015). The use of reed bed systems for methane removal from landfill leachates. Paper presented to Sardinia 2015, the fifteenth International Waste Management and Landfill Symposium, S. Margherita di Pula, Cagliari, Italy; 5-9 October 2015, CISA, Italy.

Robinson, H. (2017). Removal of dissolved methane and sulphides from landfill leachates. Paper presented to Sardinia 2017, the sixteenth International Waste Management and Landfill Symposium, held at Forte Village, S. Margherita di Pula, Cagliari, Italy, 2-6 October 2017, In proceedings and on CD-ROM.

Robinson, T. (2017). The use of reed beds for leachate treatment at closed landfill sites. Paper presented to Sardinia 2017, the sixteenth International Waste Management and Landfill Symposium, held at Forte Village, S. Margherita di Pula, Cagliari, Italy, 2-6 October 2017, In proceedings and on CD-ROM.

Robinson, T., Robinson, H. (2018). The use of reed beds for leachate treatment at closed landfill sites. Detritus. 3 (1), Pages 124-140. Available at: https://digital.detritusjournal.com/articles/the-useof-reed-beds-for-treatment-of-landfill-leachates/143

Stern, J.C., Chanton, J., Abichou, T., Powelson, D., Yuan, L., Escoriza, S. and Bogner, J. (2007). Use of a biologically active cover to reduce landfill methane emissions and enhance methane oxidation. Waste Management, Volume 27, (9), 1248-1258.

Strachan, L., Robinson, H., Last, S., Payne, G. and Wright, M. (2007). Development of leachate treatment at a large new tropical landfill site. Paper presented to Sardinia 2007, the Eleventh International Waste Management and Landfill Symposium, S Margherita di Pula, Cagliari, Italy, 1-50ctober 2007. In theProceedings on CD ROM, 10pp. 